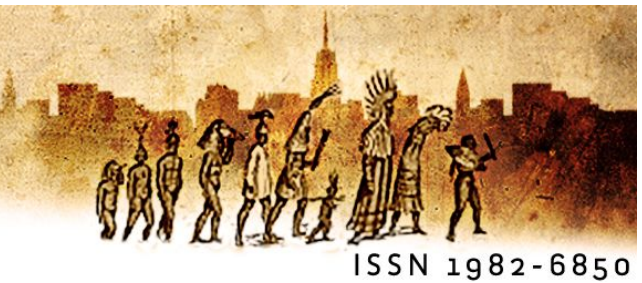

Adriana Zapparoli ${ }^{i}$

\title{
Orquídea e Vasilisa: fragmento.
}

\author{
mas vasilisa, não houve incesto... \\ e oprimido- \\ jacinthus, era tudo mentira: \\ (- eles não eram primos)
}

dali ardia a vida magenta-laranja e verde-netuno em chamas de velas em sabbat litha com aíne; enlouquecida vasilisa corria entre aloés-pimenta-seca-verbena-açafrão, carvão bétula-

lenda e um caldeirão

de quartzo...

diria agora, outra filha de baba yaga, dos ossos e das pernas dos muros encimados por crânios humanos

\section{(- por anos brilhantes aos olhos de vasilisa),}

uma jarra de óleo e um canudo, um rato cinza de pernas ossudas e um dente dente íngreme de ferro, dente que caminha entre as carnes aos pedaços pela cabana (sendo essa com perna do tipo galinácea);

ali se via vasilisa sem o abutre, um texugo e uma velha magra, que armazenava o húmus para os efeitos da ausência ...

(- ausência de orquídea) ... 
${ }^{i}$ Adriana Zapparoli (Campinas - São Paulo) é escritora e tradutora. Realizou pós-doutoramento pela Universidade Estadual de Campinas (S.P). Publicou os livros de poesia A Flor da Abissínia (versão bilíngue) em 2007; Cocatriz em 2008; Violeta de Sofia em 2009; Tílias e Tulipas (versão bilíngue) em 2010; O Leão de Neméia em 2011; Flor de Lírio (versão bilíngue) em 2012, Flor de Lótus em 2013, Flor-Cadáver em 2015, a tradução poética para Mosaico Fluido em 2014, todos os trabalhos editados pela Lumme Editor (Bauru - S.P). Em 2012 publicou a plaquete poética Lontra Corola Libido, editada pelo Centro Cultural São Paulo. Em 2015 publicou o livro de poesia para teatro Compota em Mangada, editado pelas Edições Debalde (Portugal).

* Orquídea e Vasilisa - Fragmento de texto contemplado com bolsa de incentivo à criação literária poesia Governo do Estado de São Paulo, Secretaria da Cultura, Proac Edital nº 36/ 2014. 